Art Documentation, 2002, v. 21, n.1, p. 23-26.

ISSN: 0730-7187

Link to publisher website.

Link to journal website.

(C) 2002 ART LIBRARIES SOCIETY OF NORTH AMERICA.

\title{
Citation Analysis in the Decorative Arts: A Tool for Shaping a Collection Development Policy for Serials
}

\section{by Amanda Gluibizzi, Wheelock College}

Although several citation analyses have been undertaken concerning the fine arts (notably John M. Cullars' analyses published in Library Quarterly in 1992 and 1996), there has not been much bibliographic study of the decorative arts as an independent discipline. ${ }^{1}$ As the final project of an internship in which I participated during the Spring 2001 semester, I conducted an analysis of all the serial citations listed in the fifty-four Master's theses at the Bard Graduate Center for the Study of Decorative Arts, Design \& Culture (BGC). About eight student theses are now submitted each year, with numbers increasing as the program has developed. My intent was to produce a document and information that would (or could) be useful when writing a new collection development policy for serials. ${ }^{2}$ The resulting product, a database of nearly 1,800 records, served to answer several questions I had about the methods of decorative arts research: What were the discipline-related journals most frequently cited? What date range was most common in journal and periodical citation? What topics in the decorative arts did Bard graduate students most regularly explore? And how did the citations in decorative arts theses correspond to fine arts citations as evidenced by comparison with articles on fine arts citations?

\section{Decorative Arts}

Long understood as the study of craft, that component of human aesthetic production that can be both beautiful and useful, scholarship in the decorative arts has come to encompass the topics of interior design, industrial design, fashion, and some aspects of architecture. The BGC, founded in 1993, offers the M.A. and the Ph.D. degrees (first students matriculated in 1993 and 1998, respectively) and is dedicated to addressing the assumptions that have placed the fine arts

above the decorative arts in terms of importance. ${ }^{3}$ Its programs are supported by a library of approximately 33,000 volumes and 200 periodical subscriptions, as well as by exhibitions and other programs open to the public. In addition to the BGC's own offerings, the school's Manhattan location affords its students and faculty cultural amenities such as museum exhibitions, as well as opportunities for research in specialized library collections. As the BGC's students and faculty can attest, the study of the decorative arts is no less subject to trends in scholarship and theory than other areas of the fine arts. At Bard alone, theses ranged in topic from feminist design theory to a study of the painter Boucher's china collection, from Tiffany glass to an examination of the ways that the beliefs of the Arts and Crafts Movement influenced Gandhi and the Indian Revolution. 
The study of the decorative arts is a vibrant pursuit, and it actively reflects the many facets of scholars' experiences and viewpoints.

\section{Methodology}

Because the BGC's library has a specific focus, an analysis of all the citations in the theses was not necessary to this project and, given time constraints, would not have been feasible. However, serial citations in the theses are varied enough to warrant a study that could support collection development policies in the future. With this purpose in mind, I determined that a database would be most useful as a tool to analyze citation patterns in serial titles, dates consulted, and the subjects addressed. Multiple citations to a given serial are ideal for a study such as this, but I did not want to skew the results by repeating all of the references to a single citation noted by an individual writer. Therefore, a serial citation was recorded only once per thesis author. The study was limited to serial citations listed in the bibliography and footnotes or endnotes (for reasons discussed below) and resulted in 1,792 records.

After discussion with Greta Earnest, the Chief Librarian at the school's library, I decided to classify the citations I was recording into six fields. I noted the serial title, the date of publication, the material type that was discussed (wood, glass, etc.), date range, decorative art category reflected in the subject of the citation, and the initials of the thesis author. I chose not to note the article title because I was looking only for serial titles cited, not individual articles, and because the journals cited were of primary importance. Date was recorded primarily for my own use in keeping track of what I had entered into the database and to determine the date range of the serials cited. The material type was limited to those terms considered "Materials" by the Art and Architecture Thesaurus and was intended to compare the incidence of material type with subject. ${ }^{4}$ Date range was determined in twenty-year increments (1900-1920, 1920-1940, etc.), as it was assumed that the citations would be primarily from the twentieth century, making larger groupings too broad for the purposes of the study. Subjects of the articles were determined by the titles of the articles, their citations or accompanying footnotes, and the context of the citations within the thesis's subject. I used primarily the $A A T$ genre and discipline hierarchy descriptors as subjects. ${ }^{5}$ None of the subjects chosen is a material because this distinction was limited to the material type field. Initials of the thesis authors were used to track changes and additions to the database and to remove same-author duplicate ciations from the journal name and date fields.

\section{Analysis}

The analysis began with very basic searches for serial title duplicate citations in the fields of the database. In the serial name field, 212 titles were repeated at least twice for a total of 1,422 duplicate title citations; 370 serials were cited only once. Ninety-nine of the serial titles (47\%) were related specifically to the decorative arts, either directly or to the broader area of fine arts publications, trade publications, or non-scholarly design, architecture, decorative arts, or crafts titles. Of the 212 titles, twenty-eight (13\%) were cited ten times or more. Interestingly, general audience periodicals such as The New York Times, Vanity Fair, The New Yorker, and The Sun were frequently cited. ${ }^{6}$ The remaining twenty-eight serial titles were related specifically to the decorative arts or more generally to the fine arts. Table 1 shows the top ten decorative arts-related title citations. It is partly because of the small percentage of repeated citations that researchers 
conducting citation analyses of the humanities do not suggest using such a study to determine collection development policies. ${ }^{7}$ However, the BGC may be able to find more use for this small number of very narrowly focused serials as it is a collection that primarily supports graduate and faculty research levels.

Table 2 records the date range of duplicate citations. The findings of the date range analysis were generally in keeping with prior citation analyses. A large number of the citations was restricted to the twentieth century, not surprising as the majority of the theses dealt with late nineteenth and twentieth century topics. In his analysis of fine arts monographs, Cullars found that the publication date of a monograph (in this case, thesis) studied is often reflected in the date of the references cited for the research. ${ }^{8}$ In my study, 320 citations were from nineteenth-century serials, while 1,458 citations were from twentieth-century serials, with one citation from the twenty-first century. Unlike earlier analyses conducted or cited by Cullars, the largest proportion of citations did not come from the previous twenty years." The 1920-1940 span was most often cited, with 425 records, while the 1980-2000 span was second, with 298 citations. The total amounted to less than the total of 1,792 because of twenty-year spans that were cited only once and because, surprisingly, several citations did not include the date. ${ }^{10}$

The top ten material type citations are illustrated in Table 3. Material type was the field that had the smallest number of duplicate categories. There were ten individual material types and five combinations of two types each, distinctions that occurred when two material types were discussed equally, with 1,566 citations in total. ${ }^{11}$ The metals category had the greatest number of citations at 367 , or $20.5 \%$ of all citations. Textile materials followed with 320 , or $18 \%$, citations. The Formica material, a product of new technology of the 1950s and 60s, was included in the top ten materials category.

The decorative arts category duplicates contained twenty-eight different categories with a total of 1,560 citations. Fashion design had the largest number of citations at 273. Three additional subject categories recorded more than 200 citations: furniture (269), industrial design (228), and sculpture (210). The top ten subject citations are recorded in Table 4. What is remarkable about the theses is the relatively wide range of their topics: fifteen broad subject categories served for fifty-four theses. Interestingly, the categories of fashion design and sculpture were almost entirely comprised by the citations of two authors.

Table 5 contains the top ten material types and decorative arts categories. The database program was also able to perform combination duplicate searches. Many of the results were predictable (for example, the Formica citations occurred primarily in the 1940-1960 twenty-year span, and the material type categories and journal names that allude to that specific material type correspond). The material type/decorative arts category duplicates search revealed fifty-one combinations of these two fields, with 1,530 citations. That there were still more than 250 citations that did not contain duplicates of the material type and decorative arts category further attests to the wide range of thesis topics produced by BGC students. Most of the combinations were fairly intuitive: paper (fiber products) and typography or wood and Arts and Crafts (movement). Others were less obvious, such as textile materials/paper (fiber products) and fashion design or metal and books. The combination with the greatest number of citations was textile materials and fashion design at 268 records.

I also conducted a final query of particular interest to Bard. I recorded the number of thesis author duplicates to see how many citations generally appear in graduate theses written at the BGC. Two theses contained no journal or periodical citations and one thesis contained only one periodical citation; these are not recorded in the duplicate record. Eight of the fifty-one thesis authors recorded had fewer than ten periodical citations, while several had unusually large 
numbers of citations. Three authors cited serial titles more than one hundred times $(205,169$, and 116 times). Out of the 1,792 total citations, 490 , or $27 \%$, were contributed by three authors. The average number of citations per thesis was 34.5 .

\section{Difficulties}

The most notable obstacle to the construction of the database was the inconsistency found in the thesis citations. The format of the citations varied considerably among authors, who used the MLA, Turabian/Chicago Style, variants on APA, or a combination of all three. ${ }^{12}$ Some authors listed all of the periodical citations in the bibliography, others split them between the footnotes or endnotes and the bibliography, and still others listed them exclusively in the footnotes or endnotes. Therefore, in order to record every citation, I had to comb through the text of each thesis in addition to the bibliography to record every citation, a process that unduly prolonged the database construction. The decision to use either footnotes or endnotes varied with individual authors.

Several authors used one citation for entire months' or years' runs of serials rather than citing each article separately." Many citations were incomplete or missing the date. There were many variations on the spelling of titles, particularly those that included ampersands or the word "Magazine," which was occasionally left off some citations while included in others: for example, is it Antiques or Magazine Antiques?

Other variations were not material to the analysis but could pose difficulties if the thesis citations are to be used for bibliographic references. There was little consensus on what determined a primary or secondary source. Some bibliographies featured citations that were not alphabetized, a few were marked by the author as incomplete, and foreign language titles were cited in both the original language and the English translation. Even the placement of the bibliography within the paper differed from author to author; one thesis left it off altogether. Recently, Bard has adopted one bibliographic style sheet. Had that standard been required for all theses produced at the BGC, my analysis would have been easier and more complete.

\section{Comparisons}

My serial citation analysis has corroborated John Cullars's monograph citation analyses on several points. I found, for example, that the date of the publication cited often corresponded to the time period being covered in a thesis. Furthermore, I noted that serial citations were less numerous than monograph citations (although this was not part of my study). My analysis of serial citations in the decorative arts therefore parallels studies of monograph citations in related fine arts and humanities research.

I also discovered several areas where our analyses diverged. Unlike Cullars, I found that the most recent decades (1980-2000) were not the most commonly cited in Bard's theses. Rather, the 1920-1940 span was the period most cited by BGC thesis authors. In his analyses, Cullars notes that W.C. Simonton's dissertation reported that fewer than $18 \%$ of fine arts sources were cited more than twice by different authors. ${ }^{14}$ My findings were quite the opposite. Compared to the total number of citations $(1,792)$ in the database, decorative-arts-related citations numbered 840 , or $47 \%$. In addition, when the decorative-arts-related repeated titles are compared with the total number of duplicated titles (not the total number of citations), 99 versus 212, the percentage remains the same. This can be explained by the fact that this is a study of citations from serials, 
which are less numerous than monographs, and because of the small size of the study. Another explanation may also lie in the nature of the decorative arts themselves. Because the decorative arts are meant to be useful as well as aesthetic objects, they are written about both as everyday objects and fine art objects. While the decorative arts may be considered as objects for the ages, as the fine arts are often regarded, they do not always receive that privileged status, and are also considered in the present because they are designed to be used in the present. It would make sense that a beautiful, utilitarian object could receive treatment in decorative arts journals, fine arts journals, and more popular design publications because by its nature it possesses all of these aspects. The BGC citation analysis reflects this hypothesis. The decorative arts are so prevalent in general periodical literature and citations precisely because they are everywhere.

\section{Conclusion}

It has been suggested that citation analysis is not ideal for developing collection policies for fine arts libraries. ${ }^{15}$ Because previous studies of monographs have found only small numbers of duplications in fine arts citations, because the fine arts borrow from many diverse disciplines (history, sociology, economics, to name a few) to flesh out the examination of art objects or their creators, and because monographs are still the primary source of information for bibliographic references, serial citation analysis may not reflect the reality of the use of every library collection. However, it does not follow that a library must consider quantity of publications over quality of information. While The New York Times is cited far more than any other publication, a researcher may glean more information from those less frequently cited decorative arts-related titles. The citation analysis may suggest purchasing The New York Times on microfilm even as it suggests the continuation of the subscription to Winterthur Portfolio. The results of this study are cohesive, support the concentration of the current library collection, and strengthen and justify the current serial collection development practice. Although based on a relatively small number of theses, the study serves to affirm an already solidly developing collection focused on the decorative arts.

\section{Notes}

1. John M. Cullars, "Citation Characteristics of French and German Fine Arts Monographs," Library Quarterly 66, no.2 (April 1996): 138-60 and Cullars, "Citation Characteristics of Monographs in the Fine Arts," Library Quarterly 62, no.3 (July 1992): 325-42.

2. The internship was undertaken as my semester project for Professor Paul Glassman's art librarianship class at the Pratt Institute. I appreciate the support that he and Greta Earnest, the Chief Librarian at the Bard Center, have shown for this analysis.

3. More information about the BGC's academic and public programs can be found at the school's Web site: http://bgc.bard.edu.

4. See Linda McRae on the importance of controlled vocabularies in the visual arts, particularly when concerned with discipline versus material. Linda McRae, "Indexing Images for Subject Access: Controlled Vocabularies in the VISION Project," Art Documentation 19, no.2 (2000): 7.

5. http://www.getty.edu/research/tools/vocabulary/aat/index.html.

6. The New York Times was the most frequently cited source, with 164 records, $11.5 \%$ of the duplicate serial citations and $9 \%$ of all citations in the study. Vanity Fair was cited twenty-eight times, The Sun eleven times, and The New Yorker six times.

7. Cullars, "Citation Characteristics of Monographs in the Fine Arts," p. 337.

8. Ibid., p. 338.

9. Ibid., p. 338. 
10. This curious anomaly could be the result of careless or quick citation, but I believe it could also be the result of secondhand citation: the thesis author is perhaps citing an incomplete journal citation used in another publication.

11. The number is less than the total citation number because material type was not recorded if I could not infer a decorative arts subject and material type from the citation.

12. The sources mentioned are: Joseph Gibaldi, MLA Handbook For Writers of Research Papers. 5th ed. (New York, NY: Modern Language Association of America, 1999); Kate L.Turabian, A Manual For Writers of Term Papers, Theses, and Dissertations. 6th ed rev. by John Grossman and Alice Bennett (Chicago, IL: University of Chicago Press, 1996); The Chicago Manual of Style. 14th ed. (Chicago: University of Chicago Press, 1993);

Publication Manual of the American Psychological Association. 5th ed. (Washington, DC: American Psychological Association, 2001). those dates.

13. In these instances, I recorded the date group and then removed it when I found individual citations within

14. Cullars, "Citation Characteristics of Monographs in the Fine Arts," p. 337.

15. Ibid., p. 337.

\section{References}

Art and Architecture Thesaurus Online. http://www.getty.edu/research/tools/vocabulary/aat/index.html 5 May, 2001.

Bard Graduate Center for Studies in the Decorative Arts, Design, and Culture, http://www.bgc.bard.edu, 11 November, 2001.

Cullars, John M. "Citation Characteristics of French and German Fine Arts Monographs," Library Quarterly 66, no.2 (April 1996): 138-160.

325-42. . "Citation Characteristics of Monographs in the Fine Arts," Library Quarterly 62, no.3 (July 1992):

McRae, Linda. "Indexing Images for Subject Access: Controlled Vocabularies in the VISION Project," Art Documentation 19, no.2 (Fall 2000): 4-9.

Mount, Sigrid Docken. "Evolutions in Exhibition Catalogues of African Art," Art Libraries journal 13, no.4 (1988): 14-19.

Table 1

\begin{tabular}{lc} 
Journal Title & $\#$ \\
\hline Women's Wear Daily & 92 \\
Magazine Antiques & 50 \\
American Art News & 45 \\
House \& Garden & 45 \\
Interiors & 40 \\
Arts \& Architecture & 34 \\
House Beautiful & 26 \\
Lloyd Shop News & 19 \\
Winterthur Portfolio & 19 \\
Apollo & 18 \\
\hline
\end{tabular}

Table 1: Top Ten Discipline-Related Citations

Table 2

\begin{tabular}{lc} 
Date Range & $\#$ \\
\hline $1840-1860$ & 12 \\
$1860-1880$ & 170 \\
$1880-1900$ & 138 \\
$1900-1920$ & 244 \\
$1920-1940$ & 425 \\
$1940-1960$ & 252 \\
$1960-1980$ & 239 \\
$1980-2000$ & 298 \\
\hline
\end{tabular}

Table 2: Date Range Duplicate Citations 
Table 3

\begin{tabular}{lr} 
Material Type & $\#$ \\
\hline Metal & 367 \\
Textile Materials & 320 \\
Wood & 305 \\
Mixed Media & 182 \\
Ceramic and Ceramic Products & 111 \\
Glass & 106 \\
Wood/Metal & 94 \\
Paper (Fiber Products) & 47 \\
Glass/Metal & 11 \\
Formica (TM) & 6 \\
\hline
\end{tabular}

Table 3: Material Type Duplicate Citations

Table 4

\begin{tabular}{lr} 
Decorative Arts Category & $\#$ \\
\hline Fashion design & 273 \\
Furniture & 269 \\
Industrial design & 228 \\
Sculpture & 210 \\
Chinoiserie & 104 \\
Architecture & 72 \\
Pottery & 72 \\
Jewelry & 44 \\
Textiles & 39 \\
Arts and Crafts (movement) & 30 \\
\hline
\end{tabular}

Table 4: Decorative Arts Category Duplicate Citations

Table 5

\begin{tabular}{llr} 
Material Type & $\begin{array}{l}\text { Decorative Arts } \\
\text { Category }\end{array}$ & $\#$ \\
\hline Textile materials & Fashion design & 268 \\
Metal & Sculpture & 208 \\
Wood & Furniture & 183 \\
Mixed media & Chinoiserie & 90 \\
Wood/Metal & Interior design & 80 \\
Ceramic and & & 72 \\
$\quad$ ceramic products & Pottery & 63 \\
Metal & Furniture & 62 \\
Glass & Interior design & 46 \\
Wood & Architecture & 32 \\
Metal & Jewelry
\end{tabular}

Table 5: Material Type and Decorative Arts Category Duplicate Citations 